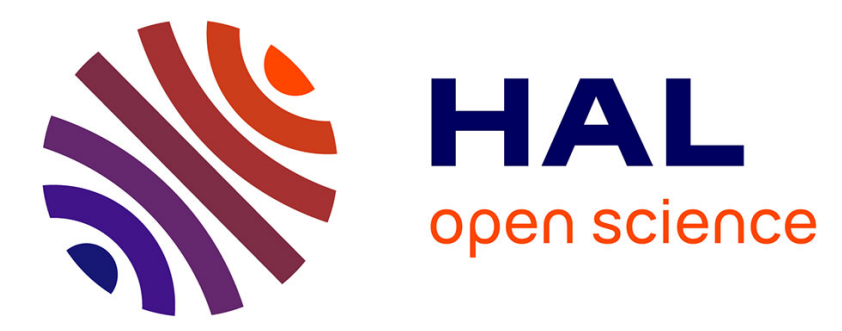

\title{
Nanofibrous clinical-grade collagen scaffolds seeded with human cardiomyocytes induces cardiac remodeling in dilated cardiomyopathy
}

Pierre Joanne, Maria Kitsara, Solène-Emmanuelle Boitard, Hany Naemetalla, Valérie Vanneaux, Mathieu Pernot, Jérôme Larghero, Patricia Forest, Yong Chen, Philippe Menasché, et al.

\section{To cite this version:}

Pierre Joanne, Maria Kitsara, Solène-Emmanuelle Boitard, Hany Naemetalla, Valérie Vanneaux, et al.. Nanofibrous clinical-grade collagen scaffolds seeded with human cardiomyocytes induces cardiac remodeling in dilated cardiomyopathy. Biomaterials, 2015, 80, pp.157-168. 10.1016/j.biomaterials.2015.11.035 . hal-01250352

\section{HAL Id: hal-01250352 \\ https://hal.sorbonne-universite.fr/hal-01250352}

Submitted on 4 Jan 2016

HAL is a multi-disciplinary open access archive for the deposit and dissemination of scientific research documents, whether they are published or not. The documents may come from teaching and research institutions in France or abroad, or from public or private research centers.
L'archive ouverte pluridisciplinaire HAL, est destinée au dépôt et à la diffusion de documents scientifiques de niveau recherche, publiés ou non, émanant des établissements d'enseignement et de recherche français ou étrangers, des laboratoires publics ou privés. 
Nanofibrous clinical-grade collagen scaffolds seeded with human cardiomyocytes induces cardiac remodeling in dilated cardiomyopathy

Pierre Joanne* $*^{1}$, Maria Kitsara $*^{2}$, Solène-Emmanuelle Boitard ${ }^{* 1}$, Hany Naemetalla ${ }^{3,4}$, Valérie Vanneaux ${ }^{5,6}$, Mathieu Pernot ${ }^{7}$, Jérôme Larghero, ${ }^{5,6,10}$, Patricia Forest ${ }^{8}$, Yong Chen ${ }^{2}$, Philippe Menasché $^{3,9,10}$, Onnik Agbulut ${ }^{1}$

${ }^{1}$ Sorbonne Universités, UPMC Univ Paris 06, Institut de Biologie Paris-Seine (IBPS), UMR CNRS 8256, Biological Adaptation and Ageing, 75005, Paris-France.

${ }^{2}$ Ecole Normale Supérieure-PSL Research University, Sorbonne Universités, UPMC Univ Paris 06, UMR CNRS 8640, PASTEUR, 75005, Paris-France.

${ }^{3}$ Université Sorbonne Paris Cité, Univ Paris Descartes, INSERM U970, 75015, Paris-France.

${ }^{4}$ Assistance Publique-Hôpitaux de Paris, Hôpital Européen Georges Pompidou, Department of Cardiology, 75015, Paris-France.

${ }^{5}$ Assistance Publique-Hôpitaux de Paris, Hôpital Saint-Louis, Unité de Thérapie Cellulaire, 75010, Paris-France.

${ }^{6}$ INSERM UMR 1160, Centre d'Investigation Clinique en Biothérapies (CIC1427), 75010, ParisFrance.

${ }^{7}$ Institut Langevin, ESPCI ParisTech, PSL Research University, UMR 7587 CNRS, U979 INSERM, Paris-France.

${ }^{8}$ Biom'Up, 69800, Saint-Priest-France.

9 Assistance Publique-Hôpitaux de Paris, Hôpital Européen Georges Pompidou, Department of Cardiovascular Surgery, 75015, Paris-France.

${ }^{10}$ Université Sorbonne Paris Cité, Paris, France.

* These authors contributed equally

\section{Corresponding author:}

Pr. Onnik Agbulut

Institut de Biologie Paris-Seine, UMR CNRS 8256

7, quai St Bernard (case 256), 75005 Paris-France

Tél:+33-1-44.27.34.21

Fax:+33-1-44.27.51.40

email: onnik.agbulut@upmc.fr 


\begin{abstract}
Limited data are available on the effects of stem cells in non-ischemic dilated cardiomyopathy (DCM). Since the diffuse nature of the disease calls for a broad distribution of cells, this study investigated the scaffold-based delivery of human induced pluripotent stem cell-derived cardiomyocytes (hiPS-CM) in a mouse model of DCM. Nanofibrous scaffolds were produced using a clinical grade atelocollagen which was electrospun and cross-linked under different conditions. As assessed by scanning electron microscopy and shear wave elastography, the optimum crosslinking conditions for hiPS-CM colonization proved to be a $10 \%$ concentration of citric acid crosslinking agent and 150 minutes of post-electrospinning baking. Acellular collagen scaffolds were first implanted in both healthy mice and those with induced DCM by a cardiac-specific invalidation of serum response factor (SRF). Seven and fourteen days after implantation, the safety of the scaffold was demonstrated by echocardiography and histological assessments. The subsequent step of implantation of the scaffolds seeded with hiPSCM in DCM induced mice, using cell-free scaffolds as controls, revealed that after fourteen days heart function decreased in controls while it remained stable in the treated mice. This pattern was associated with an increased number of endothelial cells, in line with the greater vascularity of the scaffold. Moreover, a lesser degree of fibrosis consistent with the upregulation of several genes involved in extracellular matrix remodeling was observed. These results support the interest of the proposed hiPSCM seeded electrospun scaffold for the stabilization of the DCM outcome with potential for its clinical use in the future.
\end{abstract}

\title{
Keywords
}

Cardiomyopathy; cardiac cell therapy; induced pluripotent stem cells; collagen scaffold; electrospinning. 


\section{Introduction}

Cardiovascular diseases are one of the major causes of mortality and morbidity in the developed countries. Among these diseases, dilated cardiomyopathy contributes to a large number of patients with heart failure (1). Despite advances in drug management and interventional procedures, the treatment of dilated cardiomyopathy remains a challenge because, in contrast to the ischemic forms of heart failure which are amenable to palliative procedures like revascularization, valve repair or remodeling operations, the only option here is cardiac replacement once the disease has reached an end-stage of drug refractoriness $(1,2)$. In spite of its efficacy, heart transplantation remains associated with major hurdles including organ shortage, complications of immunosuppression, and late graft vasculopathy. Permanent implantation of an assist device as destination therapy may be an alternative but remains also fraught with several complications like neurologic events, gastro-intestinal bleeding and drive line-related infections (3). In this setting, less invasive approaches like cardiac stem cell therapy would represent a promising therapeutic strategy for this category of heart failure patients.

Stem cell therapy for cardiac repair has been extensively studied in acute myocardial infarction (4-6) and chronic ischemic heart disease (7-9), showing a potential, albeit often marginal, benefit but few studies are available in the context of dilated cardiomyopathy (10-12). The objective of improving pump function through replenishment of the diseased myocardium by "new" cardiomyocytes (CM), regardless of whether they derive from the grafted cells or from endogenous cardiac stem cells activated by transplant-released biomolecules, has been dramatically boosted by the possibility of generating cardiac cells from human induced pluripotent stem cells (hiPS) (13). For example, Lian et al. have demonstrated that, by using a timely-defined regulation of the Wnt/ $\beta$-catenin signaling pathway, it is possible to generate CM from various hiPS lines (14). However, the therapeutic efficacy of stem cell therapy is not only influenced by the cell phenotype but is also critically dependent on the mode of cell transfer $(15,16)$. From this standpoint, the diffuse nature of the disease in dilated cardiomyopathy represents a sound indication for an extensive coverage of the ventricle by a cellseeded scaffold, the clinical implementation of which could take advantage of the recent advances in minimally invasive approaches to the heart.

One of the main considerations to be then taken into account in the development of cardiac patch is the role of environmental cues in guiding differentiation events and cell survival $(17,18)$ which mandates a material as biomimetic as possible. We therefore selected collagen which is both the most abundant protein of cardiac extra-cellular matrix $(19,20)$ and a highly biocompatible polymer. Collagen fibers are also capable of force transmission and signaling via their mechanical and biological properties.

Thus, electrospun nanofibrous collagen scaffolds represent a very promising option to deliver iPS-CM to the heart (21). Electrospinning is an established nanotechnology technique for fabricating nanofibers by electrically charging a polymeric solution and has been extensively used for the fabrication of biomaterial scaffolds for tissue engineering (22-24).

In a recent work, we have demonstrated the feasibility of obtaining electrospun collagen scaffolds with biologically-compatible solvents and cross-linking agents (25). In the present study, we leveraged these previous data to generate nanofibrous collagen scaffolds seeded with hiPS-CM and epicardially delivered these scaffolds in a mouse model of dilated cardiomyopathy based on the cardiac-specific and tamoxifen-inducible invalidation of serum response factor (SRF). Care was taken to use a collagen which is clinically validated to improve the clinical relevance and translatability of the generated data. The in vivo results of the current work indicated the feasibility of the proposed hiPS-CM seeded electrospun scaffold for the stabilization of the DCM outcome with potential for its clinical use in the future. 


\section{a. Electrospinning}

Clinical-grade atelocollagen in the form of dry material was provided by Biom'Up (Saint-Priest, France). The raw product was dissolved using a bioacceptable solvent system based on ethanol, water and salts (26). For the cross-linking of the collagen scaffolds, a system containing citric acid (CA), glycerol as the extending agent and sodium hypophosphite (SHP) as a catalyst was used (27). Different concentrations of CA and SHP were studied: 5\% CA with 2.5\% SHP and 10\% CA with 5\% SHP (weight percentage based on the weight of collagen). The final solution was electrospun by applying $13.5 \mathrm{kV}$ voltage between the syringe needle and the collector (flow rate: $1 \mathrm{ml} / \mathrm{h}$, distance to collector: $5 \mathrm{~cm}$, temperature: $20 \pm 2^{\circ} \mathrm{C}$ ). After electrospinning, a post-treatment cross-linking was applied to the scaffolds by baking them at $150^{\circ} \mathrm{C}$ for three different periods $(90,120$ or 150 minutes). For more details, see Supplemental Materials. Circular dichroism was used to study denaturation of collagen after the electrospinning. Scanned electron microscopy was used to visualize the structure of the generated scaffolds. These two methods are described in the Supplemental Materials section.

\section{b. Elasticity measurements}

The ShearWave ${ }^{\mathrm{TM}}$ Elastography imaging mode is a real time ultrasound imaging mode that quantitatively measures elasticity in soft tissue (28). The principle of ShearWave ${ }^{\mathrm{TM}}$ Elastography relies on imaging at very high frame rate $(5,000 \mathrm{images} / \mathrm{s})$ the propagation of a shear wave remotely induced by the acoustic radiation force. The shear modulus map is then derived directly from the local shear velocity measured in the sample. A $15 \mathrm{MHz}$ central frequency ultrasound transducer connected to an AixPlorer ${ }^{\circledR}$ ultrasound scanner (Supersonic Imagine, Aix-en-Provence, France) was used for this purpose. Real-time B-mode imaging was used to measure the thickness of the samples. Shear wave propagation speed was calculated from scaffolds in aqueous solution. A color-coded, real-time shear wave elastography map could then be produced to quantitatively assess the shear velocity. A correction was applied on the shear velocity to take into account the wave guided effect in thin wall as in (29) and finally obtain quantitative values of the Young's modulus.

\section{c. Cells}

The human episomal iPS cell line (hiPS, Life Technologies, Saint-Aubin, France) was used in this study from passage 4 to passage 10 and cultured as indicated in the manufacturer's instructions. Details are provided in the Supplemental Materials section. Neonatal rat cardiomyocytes were purified as described in that same section. Two-hundred thousand cells were seeded on a collagen scaffold maintained with a CellCrown ${ }^{\mathrm{TM}}$ (Scaffdex, Tampere, Finland) in a 24-well plate and after three days of culture, the cells were fixed and immunolabeled with Nkx2.5 (Santa Cruz Biotechnology, Heidelberg, Germany) and $\alpha$-actinin (Sigma-Aldrich, Saint-Quentin-Fallavier, France) antibodies to determine the percentage of cardiomyocytes.

\section{d. hiPS cardiac differentiation}

To obtain a sufficient amount of cells for differentiation, a cryovial of hiPS cells was thawed and amplified for two passages on Matrigel® hESC-Qualified Matrix (Corning Life Sciences, Amsterdam, The Netherlands), in $\mathrm{mTeSR}^{\mathrm{TM}} 1$ medium (Stemcell Technologies, Grenoble, France) as described previously $(14,30)$. Cells were then differentiated using the GiWi protocol (14) at $37^{\circ} \mathrm{C}$ and $5 \% \mathrm{CO}_{2}$. Briefly, cells were detached using accutase (StemPro®-Accutase ${ }^{\circledR}$ Cell Dissociation Reagent; Life Technologies) and counted. Undifferentiated cells were seeded on Matrigel@ hESC-Qualified Matrix coated wells of a 6 -well plate $\left(2.4 \times 10^{6}\right.$ cells/well $)$ in $\mathrm{mTeSR}^{\mathrm{TM}} 1$ supplemented with $5 \mu \mathrm{M}$ of $\mathrm{Y} 27632$ (ROCK inhibitor, Tocris Bioscience, Bristol, United Kingdom) and cultured during 3 additional days with daily replacement of $\mathrm{mTeSR}^{\mathrm{TM}} 1$. Cardiac differentiation was then initiated by reverting the medium to RPMI (Life Technologies) enriched with 2\% insulin-free B27 supplement (Life Technologies) and $10 \mu \mathrm{M}$ CHIR99021 (Selleckchem, Houston, TX, USA). This medium was replaced with RPMI supplemented with B27 minus insulin after 24 hours. Two days later, the medium was half exchanged for fresh RPMI-B27 minus insulin containing $5 \mu \mathrm{M}$ of IWP2 (Tocris Bioscience) for 48h. Seven days after the addition of CHIR99021, the medium was replaced by RPMI enriched with $2 \%$ 
B27 supplement, and the very first beating cell clusters were observed the day after. At day 15, cells were thus recovered with accutase, passed through a $70 \mu \mathrm{m}$ cell strainer (BD Biosciences, Le Pont de Claix, France) and counted. Purity was confirmed by cytometry (see Supplemental Methods). Then, $10^{6}$ cells were seeded on a collagen scaffold fixed to a CellCrown ${ }^{\mathrm{TM}}$ (Scaffdex) in a 24-well plate with RPMI supplemented with $2 \%$ B27. After two days, the medium was changed and, one day later, the scaffold was removed and grafted on the heart of mice.

\section{e. Animals}

All procedures were approved by our institutional Ethics Committee and complied with the European legislation (Directive 2010/63/EU) on animal care. In this study, a total of 56 mice were used, which included 32, 6 to 9-month-old conditionally invalidated serum response factor ( $\alpha \mathrm{MHC}$ MerCreMer:Sf/Sf (31) mice and 24 C57BL6 mice. The Cre-mediated excision of floxed serum response factor (SRF) alleles in the heart was induced by daily intraperitoneal tamoxifen $(20 \mu \mathrm{g} / \mathrm{g} / \mathrm{day}$; Sigma-Aldrich) injections on 3 consecutive days. Mice were grafted three weeks after the last tamoxifen administration.

\section{f. Epicardial grafting}

Animals underwent a left lateral thoracotomy after intraperitoneal ketamine $(100 \mathrm{mg} / \mathrm{kg}$; Merial, Gerland, France)-xylazin (10 mg/kg; Bayer, Puteaux, France) anaesthesia and tracheal ventilation. Analgesia was performed for 2 days after surgery with a $2 \mathrm{mg} / \mathrm{kg}$ intraperitoneal injection of profenid® (Merial). Collagen scaffolds (surface approximately $200 \mathrm{~mm}^{2}$ ) were sutured on the ventricles of 24 healthy C57BL6 and $26 \alpha$ MHC-MerCreMer:Sf/Sf mice. Six additional $\alpha$ MHCMerCreMer:Sf/Sf mice (Sham) underwent the same procedure without scaffold implantation and served as sham-operated controls. All $\alpha \mathrm{MHC}$-MerCreMer:Sf/Sf mice were daily treated with cyclosporine A $(10 \mathrm{mg} / \mathrm{kg} / \mathrm{day}$, intraperitoneal; Novartis Pharma, Rueil-Malmaison, France) until the echocardiographic assessment of heart function at 14 days after the implantation. C57BL6 mice were sacrificed 7 days after treatment to assess the biocompatibility of collagen scaffold. All mice were sacrificed by cervical dislocation and then hearts were removed, the left ventricle apexes were dissected and flash-frozen in liquid nitrogen for subsequent RNA isolation. The remaining hearts were embedded in Tissue-Tek (Sakura Finetek, Villeneuve d'Ascq, France) and frozen in liquid nitrogencooled isopentane until they were sliced into $10 \mu \mathrm{m}$ thick cryosections for histology and immunostaining (see Supplemental Methods).

\section{g. Cardiac function}

Pre- and post-transplantation cardiac function was evaluated by transthoracic echocardiography (Sequoia 516, equipped with a $13 \mathrm{MHz}$ phased-array linear $15 \mathrm{~L} 8$ probe; Siemens, Saint-Denis, France) in animals sedated with $2 \%$ isoflurane. Two-dimensional parasternal long-axis views were used to measure the left ventricular end-diastolic and -systolic volumes (LVEDV and LVESV, respectively). Ejection fraction (EF) was calculated as described previously (9). All measurements were made online on freeze frame images in triplicate and averaged by an investigator blinded to the treatment group.

\section{h. Gene expression}

Details of the procedure and sequences of primers used are available in Supplemental Methods.

\section{i. Statistics}

Groups were statistically compared using analysis of variance (ANOVA). If necessary, post-hoc analysis was performed using Tukey's Honestly Significant Difference (HSD) test in R software. For groups that did not pass tests of normality (Shapiro-Wilk) and equal variance (Bartlett or Fisher), nonparametric tests were used (Kruskal-Wallis) and multiple comparison were driven using the Dunn procedure and multivariate normal distribution in $\mathrm{R}$ software. Values are given as means \pm SEM. All outcome measurements were made blindly. 


\section{a. Physical characteristics of collagen scaffolds}

After electrospinning and cross-linking under different conditions of CA concentration and baking time, the structure of the different scaffolds was checked by scanning electron microscopy (Figure 1AB). A nanofibrous structure was observed in all tested conditions without major structural differences between them (Supplemental Figures S1 and S2A-B). Then, the effect of the solution preparation and electrospinning on the denaturation of collagen was studied by circular dichroism. Our results demonstrated that after the electrospinning process the fraction of the folded collagen is approximately $70 \%$ (Supplemental Figure S2C).

The scaffold parameters were further evaluated from scanning electron microscopy images. The fiber thickness for all the different cross-linking conditions ranged from 0.6 to $2.2 \mu \mathrm{m}$ with an average porosity of $2-3 \mu \mathrm{m}$. No differences between the cross-linking conditions were observed. The maximum porosity was close to $7 \mu \mathrm{m}$.

Shear wave elastography was used for measuring the thickness and elasticity of the collagen scaffolds. The thickness of the different collagen scaffolds was $400 \pm 50 \mu \mathrm{m}$. Their stiffness, evaluated as the Young's modulus, increased with the CA concentration and the baking time (Figure 1C) and peaked for the $10 \%$ CA with 150 minutes-baking condition $(10.1 \mathrm{kPa})$.

\section{b. Biocompatibility of collagen scaffolds}

The biocompatibility of the different collagen scaffolds was studied both in vivo (grafting of scaffolds in C57BL6 mice) and in vitro (seeding of scaffolds with neonatal rat cardiomyocytes). Thus, to first assess the biocompatibility of the electrospun collagen construct in a cardiac environment, we grafted acellular scaffolds on the surface of the heart of 24 healthy C57BL6 mice. After 7 days, the hearts were explanted and analyzed. Hematoxylin-eosin staining showed that the collagen scaffolds were macroscopically visible in all conditions (Figure 2A) with evidence for some degradation manifest as pores in the scaffold (Figure 2B, Supplemental Figure S3). Quantification of this porosity (Figure 2C) indicated that, despite the lack of significant differences, cross-linked scaffolds baked during 150 minutes seemed to present less degradation than those processed under the other conditions. This is also supported by the finding that scaffolds baked during 150 minutes were found in all animal tested unlike those undergoing a shorter baking time ( $\mathrm{n}=4$ per group, a total 6 groups, data not shown). Furthermore, in all conditions tested, numerous blood vessels were identified within the scaffold and in the underlying myocardium in close proximity to the scaffold, as evidenced by positive CD31 and caveolin-1 $\alpha$ stainings (Figure 2D). The biocompatibility of electrospun collagen nanofibers was further supported by in vitro experiments using neonatal rat cardiomyocytes (Figure 2E-F). As shown in Figure 2F, not all cells were positive for $\alpha$-actinin or $\mathrm{Nkx} 2.5$, which is consistent with the remaining presence of contaminating fibroblasts in the cell culture. The quantification of the ratio between cardiomyocytes and non-cardiomyocytes after 3 days of culture (Figure 2E) indicated, however, that collagen scaffolds cross-linked with $10 \% \mathrm{CA}$ allowed a greater colonization of the construct by cardiac cells. Moreover these cardiac cells were larger and wider, with a better-looking morphology and a more organized sarcomeric structure (Figure 2F). Put together, these data led to conclude that $10 \%$ CA-based cross-linking was the best condition for generating collagen scaffolds for cardiac cell therapy applications.

\section{c. Lack of deleterious effects of acellular collagen scaffolds on heart function}

To complete the biocompatibility testing, we then assessed whether collagen scaffolds could have a deleterious effect on heart function. To this end, $10 \%$ and 5\% CA-cross-linked collagen cell-free scaffolds were epicardially delivered in the $\alpha \mathrm{MHC}-\mathrm{MerCreMer:Sf} / \mathrm{Sf}$ mouse model of dilated cardiomyopathy $(\mathrm{n}=18)$. Fourteen days after delivery (35 days after tamoxifen injection), LVEDV, LVESV and EF were measured. At this time point, tamoxifen treated $\alpha \mathrm{MHC}-\mathrm{MerCreMer:Sf/Sf}$ mice exhibited impaired cardiac function. As shown in Figure 3, no statistical differences in cardiac function were observed between sham-operated mice and mice treated with $5 \%$ or $10 \%$ ( $\mathrm{n}=6$ per 
group) CA acellular collagen scaffolds (Figure 3A-C). Likewise, no differences were observed in the expression of the hypertrophic markers beta-myosin heavy chain $(\beta-\mathrm{MHC})$, atrial natriuretic factor (Anf) and brain natriuretic peptide (Bnp) (Figure 3D-F). These results thus confirmed that, under our conditions of material processing, electrospun collagen scaffolds did not adversely affect heart function.

\section{d. Improvement of cardiac function by human pluripotent stem cell- derived cardiomyocytes seeded on collagen scaffolds}

Based on the previous results, a collagen scaffold cross-linked with 10\% CA was selected for seeding with cardiomyocytes-derived from hiPS. More than $70 \%$ of cells expressing cardiac troponin, as demonstrated by flow cytometry, were obtained after 15 days with the biphasic activation/inhibition of the Wnt pathway differentiation protocol (14) (see Figure 4A-B). These cells were cultured for 3 days onto the scaffold. As seen in Figure 4C, the cells colonized the 10\% CA collagen scaffold featuring a regular distribution of the sarcomeric protein $\alpha$-actinin. Of note, contraction of the scaffold could be observed (see Supplemental Data video1), indicating a functional colonization and a good compatibility between the hiPS-CM and their collagen support. These scaffolds were then epicardially delivered in $8 \alpha \mathrm{MHC}-\mathrm{MerCreMer:Sf/Sf}$ mice three weeks after tamoxifen induction. Six acellular collagen scaffolds $(10 \% \mathrm{CA})$ were used as controls. Baseline functional parameters did not differ significantly between the two groups $(p>0.05)$. In contrast, as demonstrated in figure 4 , at sacrifice (14 days after implantation), all functional parameters including LVESV, LVEDV and EF significantly differed between the two groups $(p<0.001)$. There was a marked increase in LVESV and LVEDV over baseline in mice treated with the cell-free scaffolds $(36.04 \pm 0.84 \mu \mathrm{L} v s 27.81 \pm 0.64 \mu \mathrm{L}, p=0.001$; $51.77 \pm 1.50 \mu \mathrm{L}$ vs. $44.41 \pm 0.81 \mu \mathrm{L}, p=0.003$, respectively). In contrast, mice treated with the $10 \% \mathrm{CA}$ scaffold+hiPS-CM demonstrated stable values of these functional parameters throughout the experimental time course $(22.32 \pm 1.73 \mu \mathrm{L}$ at sacrifice $v s 25.38 \pm 1.09 \mu \mathrm{L}$ at baseline for LVESV, $p=0.28 ; 41.28 \pm 1.24 \mu \mathrm{L} v s 43.33 \pm 1.20 \mu \mathrm{L}$, respectively for LVEDV, $p=0.78$ ). EF featured similar patterns (Figure $4 \mathrm{~F}$ ). This improvement was associated with the strong decrease in the expression of $\beta$ MHC $(p=0.044)$ and an increased expression of cardiac actin $(p=0.044)$ (Figure 4G).

\section{e. Improvement of the scaffold vascularization induced by cardiomyocytes derived from human pluripotent stem cells}

To decipher the mechanisms behind the improvement of heart function, we first tried to find human cells in the heart of mice or in implanted scaffolds. However, no human cells were observed 14 days after transplantation (data not shown), indicating that the effects observed were likely due to activation of signaling pathways in the recipient's heart in response to the transplanted cells. As shown in Figure 5 , there was a strong increase in the number of CD31-positive cells in the cellularized collagen scaffold compared to the acellular one (Figure 5A, B and D). Interestingly, mice treated with the hiPSCM-loaded scaffold demonstrated a significant increase in SRF gene expression $(p=0.01$, Figure 5C), consistent with the increase in CD31-positive cells that are known to express SRF. There were no obvious histological patterns of a xenogeneic immune response to the delivered human iPS cardiac derivatives, as evidenced by the lack of difference in the extent of macrophage and T-lymphocyte infiltration between the cell-free and the cell-loaded scaffolds groups 14 days after treatment (data not shown).

\section{f. Cardiac cells derived from human pluripotent stem cells induce a closer adherence of the scaffold to the heart}

As shown by hematoxylin-eosin and Sirus red stainings in Figure 6, implanted collagen scaffolds were visible at the surface of the heart 14 days after transplantation in both groups. However, a closer analysis demonstrated some differences between the two groups. As shown in Figure 6A and 6B, a thin layer of interstitial cells were found between the surface of the heart and the cell-free scaffold whereas these cells were not detectable following implantation of the cell-loaded scaffold (Figure 6C and 6D) which thus appeared more closely adherent to the implantation area. This closer contact of the cellularized collagen construct with the host myocardium, as compared with the cell-free scaffold, 
could have allowed the seeded cells to more effectively control the expected procedure-induced inflammatory response and its attendant fibrotic sequelae, thereby accounting for the above mentioned reduction in ventricular volumes. This hypothesis is actually consistent with a marked, albeit not significant, treatment-induced increase in the expression of several genes implicated in the regulation of extracellular matrix such as osteopontin, tissue inhibitor of metalloproteinase 1 (Timp1), thymus cell antigen-1 (Thy1), collagen 3a1 and collagen 1a1 (Figure 6F).

\section{Discussion}

The main result of this study is that epicardial delivery of an electrospun collagen scaffold seeded with hiPS-CM improves the functional outcomes of non-ischemically dilated mouse hearts. The scaffold was well integrated into the host myocardium but the hiPS-CM that it initially harbored were no longer detectable after 14 days and are thus postulated to have acted paracrinally on endogenous repair pathways, as suggested by the increased vascularity and potentiated integration of the scaffold compared with hearts receiving the cell-free collagen patch.

Non-ischemic dilated cardiomyopathy is characterized by the loss of a critical number of cardiomyocytes causing a decrease of myocardial contractility (1) and a compensatory cardiac remodeling which may ultimately result in heart failure (32). Unlike ischemic cardiac diseases, dilated cardiomyopathy is not amenable to palliative procedures like coronary artery revascularization or mitral valve repair and, indeed, now exceeded coronary artery disease as an indication for heart transplantation (55\% vs 36\%) in the last report of the International Society for Heart and Lung Transplantation (33). There is thus a robust rationale for investigating new therapies, among which stem cells may hold some promise. Even though cell therapy is unlikely to afford a total replacement of the diffusely diseased tissue with "new" cardiomyocytes, it could still be efficacious by harnessing endogenous repair pathways via mitigation of adverse remodeling, increased angiogenesis or activation of resident stem cells (34). Furthermore, usual needle-based multiple intramyocardial injections may not be the most suitable mode of cell transfer because of the diffuse nature of the disease while this hurdle could be overcome by the epicardial delivery of a cell-loaded scaffold "wrapping" a large area of the left ventricle and potentially delivered through a minimal access procedure. Beyond the provision of reparative cells, such a tissue-engineered construct could also be useful by mechanically supporting the heart, thereby limiting its adverse remodeling (35). Putting these data together led to the design of the present study entailing the evaluation of an engineered collagen patch loaded with hiPS-CM.

Several natural and synthetic polymers have been investigated as tissue-engineered cardiac constructs. Among them, collagen features distinct advantages. It is an essential component of myocardial connective stroma, which is largely composed of type I and III fibrillar collagen (19) and its arrangement may contribute to preserve heart microarchitecture and chamber geometry. Actually, several reports have emphasized that the architecture of myocardial collagen fibers, in particular of the endomysium, may be involved in the regulation of the mechanical activity of the heart $(36,37)$. In addition, collagen can interact with most cell types to promote their adhesion, survival and growth. Finally, collagen has a long-standing safety record for medical applications, which should streamline translational processes towards the clinics. For all these reasons, we selected collagen as the patch material and used electrospinning to generate biomimetic nanofibrous scaffolds intended to recapitulate extracellular matrix properties (21). Like in our previous study (25), care was taken to use a clinically validated atelocollagen, which is more soluble, less antigenic and more biocompatible than native collagen, collagen peptide or gelatin, and to rely on biocompatible solvents. This resulted in a post-electrospinning denaturation rate of $30 \%$, which is in good agreement with previously reported studies on the effect of the electrospinning process on the collagen structure (27). Different postelectrospinning cross-linking conditions were then tested to modulate the stiffness of the collagen scaffolds. The best combination was obtained with $10 \%$ of CA and 150 minutes of baking at $150^{\circ} \mathrm{C}$, which resulted in an elasticity modulus of $10.1 \mathrm{kPa}$. It should be noted that the elastic modulus of native heart tissue is in the range of $10-15 \mathrm{kPa}$ (38) while the elastic modulus of ischemic tissue, associated with fibrosis, increases around $30-50 \mathrm{kPa}$ (39-40). Furthermore, Engler et al. (38) using isolating cardiac cells have demonstrated that cardiomyocytes were only able to form mature sarcomeres with regular beating on polyacrylamide gels of about $10 \mathrm{kPa}$. On softer gels, sarcomeres 
were less spaced and not fully organized whereas on stiffer gels, myocytes contained more stress fibers and did not display sarcomeres. Thus, the elasticity value of our collagen scaffold falls in the range of those reported for optimizing cardiac tissue regeneration, 10-20 $\mathrm{kPa}(17)$, and the suitability of this degree of elasticity for the intended applications is supported by the finding of an interconnecting functional cardiac-like tissue three days after the cardiomyocytes had been seeded onto the scaffold (Figures 2E and 4C and Supplemental Video 1).

The next issue was the choice of the cells to be grafted. Although there is not yet a consensus regarding the identity of the "ideal" cell, head-to-head studies suggest that the greatest therapeutic efficacy is obtained by using cells committed to the cardiac lineage, as compared to non-cardiac cells (41-45). Of note, the superiority of cardiac-committed cells has been demonstrated on the basis of multiple endpoints (engraftment, reduction of infarct size and fibrosis, angiogenesis, improvement in function and limitation of arrhythmias) and might be related to stronger and more target tissue-specific paracrine effects (43). For this reason, we selected to use hiPS-derived cardiomyocytes which have been shown to recapitulate most, if not all, the molecular, electrophysiological and functional fingerprints of bona fide cardiomyocytes. Over the past years, tremendous improvements have been made in the generation of hiPS-CM by mimicking in vitro, developmental pathways normally operating during embryonic cardiogenesis (13) and, in the present study, an efficient cardiomyogenic differentiation of pluripotent hiPS cells could be achieved by a sequential activation/inhibition of the Wnt pathway $(14,30)$. In keeping with their cardiac phenotype, intramyocardial injections of these cells have been shown to give stable (46), electrically integrated (47) and vascularized grafts (8). Transplantation of these cells delivered under the form of cell sheets has also been successful in providing functional and electrical recovery of infarcted hearts (48). However, our past experience with cell sheets has identified potential issues related to their fragilty and difficulty in handling. This issue was addressed by using the above-mentioned collagen patch as a cell carrier featuring stronger handling characteristics, including suturability, and more tunable mechanical properties.

These hiPS-CM-loaded collagen patches were then grafted in a double transgenic mouse model ( $\alpha$ MHC-MerCreMer:Sf/Sf) which allows to induce the inactivation of SRF only in cardiomyocytes as tamoxifen-inducible Cre recombinase expression is under the control of the cardiomyocyte-specific alpha myosin heavy chain promoter $(\alpha \mathrm{MHC})$. SRF mRNA and protein levels drastically decrease after tamoxifen injection and mice exhibit a progressive impairment of cardiac contractility, ending up in dilated cardiomyopathy, heart failure, and death within 10 weeks $(31,49)$. The present results clearly demonstrate the efficacy of the cellularized collagen construct in stabilizing the contractile function of SRF-deficient transgenic mice since, two weeks after patch implantation, LV volumes and EF were significantly improved in treated mice compared with their cell-free counterparts. This functional benefit was paralleled by a PCR-evidenced significant decrease of $\beta$-MHC taken as a surrogate marker of heart failure.

However, by the time the functional outcome was found better preserved by the hiPS-CM-loaded patch, the grafted cells were no longer detectable. Such a discrepancy has been repeatedly reported in the literature and cell loss is now attributed to an interplay of multiple factors among which an immune response against hiPS, despite cyclosporine therapy, cannot be eliminated (discussed below). The inability to explain the functional benefits of stem cells by their sustained engraftment has given rise to the paracrine hypothesis whereby biomolecules released by the cells would foster endogenous repair pathways. This hypothesis is indirectly supported by our data, assuming that SRF expression in endothelial cells is unaffected in this model (50). Thus, the increased expression of SRF in the heart of treated mice could reflect a paracrinally-mediated augmentation of the pool of endothelial cells, which would be consistent with the definite trend towards a greater capillary density in the scaffold and, to a lesser degree, in the neighboring myocardium. Admittedly, however, part of this increased vascularity could be due to the collagen material itself which is known to have intrinsic angiogeneic properties (51). Finally, the cellularized collagen scaffold was associated with the upregulation of several genes involved in the regulation of extracellular matrix remodeling and a trend towards a lesser degree of fibrosis (Figure 6D-E). In particular, osteopontin has been described as an important regulator of matrix metalloproteinases and their tissue inhibitors during remodeling, resulting in significantly decreased left ventricular dilation after myocardial infarction (52). In agreement with this observation, the increase in osteopontin expression seen in the treated group was paralleled with that of Tissue 
Inhibitor Matrix Metalloproteinase (Timp)-1 mRNA levels. Of note, the expression of these genes was based on apical heart sections, remote from the scaffold implantation area, which may have led to underestimate their level of upregulation but lends further credit to the release of molecules diffusing from the patch throughout the myocardium. Admittedly, an alternate mechanism whereby the cellloaded scaffolds improved left ventricular function could be the putative cardioprotective effect of some of the effectors of the xenogeneic immune response expected to occur when human cells are transplanted in a mouse heart (53). However, (1) in an immunodeficient mouse model where no rejection would be expected to occur, transplantation of human pluripotent stem cell-derived early progenitor cells was shown to preserve postinfarction myocardial function whereas fibroblasts, also from human origin, did not (54), (2) in an immunocompetent mouse model, transplantation of human fibroblasts failed to show any functional benefit despite the immune response expected to have occurred in this xenogeneic context (55), (3) a previous study from our laboratory has shown only limited functional benefits of transplantation of allogeneic adipose-derived stem cells (12) while in the same DCM model, human skeletal myoblasts have equally failed to significantly improve heart function (unpublished data), and, (4) in the present experiments, both immunostaining and qPCR failed to demonstrate a noticeable difference in the extent of macrophage and T-lymphocyte infiltration between the cell-free and the cell-loaded scaffolds, thereby suggesting the efficacy of our cyclosporine-based immunosuppression in mitigating the expected xenogeneic immune response. Collectively, these data make unlikely that the functional benefits of the cell-loaded scaffolds could be fully explained by a nonspecific immune response and they rather support that the presence, at least early after scaffold implantation, of the iPS-derived cardiomyocytes directly contributed to the improved outcomes yielded by the cellularized constructs.

Altogether, our data converge to relate these functional benefits of hiPS-CM-loaded electrospun collagen nanofiber patches to the paracrine activation of endogenous repair pathways that still need to be precisely characterized. Likewise, the positive outcome of these constructs requires to be further validated, particularly in a clinically relevant large animal model and alternate cell/material combinations should also be tested. Yet, the present results support the concept that covering the nonischemically dilated left ventricle with a cellularized scaffold endowed with cardiomyogenic properties could be an effective means of stabilizing the disease, thereby delaying the time by which a complete cardiac replacement may become unavoidable.

\section{Conclusions}

In this study we epicardially delivered nanofibrous collagen scaffolds seeded with cardiomyocytes derived from human induced pluripotent stem cells (hiPS-CM) in a mouse model of dilated cardiomyopathy. In vivo and in vitro assays indicated the optimal electrospinning and crosslinking conditions to produce biocompatible scaffolds with stiffness comparable to those reported for optimizing cardiac tissue regeneration. In vivo results have shown a restricted thickening of the matrix extending into the scaffold and an increase, although not significant, in the expression of several genes implicated in the regulation of extracellular matrix. These results support that a hiPS-CM-loaded electrospun collagen scaffold could be utilized for the stabilization of DCM, most likely through paracrine signaling. Therefore, iPS-CM seem to potentiate the effects of collagen scaffolds and, in a broader perspective, the current results support the concept that cardiac engineering could be a therapeutically effective strategy in patients with advanced but non end-stage dilated cardiomyopathy. 


\section{Funding}

This work was supported by funds from CNRS, INSERM, University Pierre\&Marie Curie, University Paris Descartes and the ANR-12-RPIB-0015, the Fondation de l'Avenir (ET2-658 \& AP-RMA-2015036) and the LabEx REVIVE (ANR-10-LABX-73). P.J. and S.E.B. were supported by a fellowship from the Fondation Lefoulon-Delalande and the Conseil Régional d'Ile de France (DIM Biothérapies), respectively.

\section{Acknowledgements}

Authors thank Dr. Z. Li, Dr. M. Mericskay, Dr. A. Parlakian (UMR CNRS 8256, Paris, France) for scientific discussion and for providing them with a breeding pair of $\alpha \mathrm{MHC}-\mathrm{MerCreMer:Sf} / \mathrm{Sf}$ mice, A. Munier for technical assistance during flow cytometry analysis and B. Poinard for technical help during neonatal rat cardiomyocytes preparation and I. Ben Dhiab for technical help in the scaffolds preparation.

\section{Conflict of interest}

None declared. 


\section{References}

1. Hershberger RE, Morales A, Siegfried JD. Clinical and genetic issues in dilated cardiomyopathy: a review for genetics professionals. Genet Med Off J Am Coll Med Genet. 2010;12:655-667.

2. Clarke A, Pulikottil-Jacob R, Connock M, Suri G, Kandala N-B, Maheswaran H, Banner NR, Sutcliffe P. Cost-effectiveness of left ventricular assist devices (LVADs) for patients with advanced heart failure: analysis of the British NHS bridge to transplant (BTT) program. Int $J$ Cardiol. 2014;171:338-345.

3. Patel CB, Cowger JA, Zuckermann A. A contemporary review of mechanical circulatory support. J Heart Lung Transplant Off Publ Int Soc Heart Transplant. 2014;33:667-674.

4. Ale A, Siebenhaar F, Kosanke K, Aichler M, Radrich K, Heydrich S, Schiemann M, Bielicki I, Noel PB, Braren R, Maurer M, Walch AK, Rummeny EJ, Ntziachristos V, Wildgruber M. Cardioprotective $\mathrm{C}^{-k i t^{+}}$bone marrow cells attenuate apoptosis after acute myocardial infarction in mice - in-vivo assessment with fluorescence molecular imaging. Theranostics. 2013;3:903-913.

5. Thal MA, Krishnamurthy P, Mackie AR, Hoxha E, Lambers E, Verma S, Ramirez V, Qin G, Losordo DW, Kishore R. Enhanced angiogenic and cardiomyocyte differentiation capacity of epigenetically reprogrammed mouse and human endothelial progenitor cells augments their efficacy for ischemic myocardial repair. Circ Res. 2012;111:180-190.

6. Valina C, Pinkernell K, Song Y-H, Bai X, Sadat S, Campeau RJ, Jemtel TH Le, Alt E. Intracoronary administration of autologous adipose tissue-derived stem cells improves left ventricular function, perfusion, and remodelling after acute myocardial infarction. Eur Heart J. 2007;28:2667-2677.

7. Poglajen G, Vrtovec B. Stem cell therapy for chronic heart failure. Curr Opin Cardiol. 2015;30:301-310.

8. Chong JJH, Yang X, Don CW, Minami E, Liu Y-W, Weyers JJ, Mahoney WM, Biber B Van, Cook SM, Palpant NJ, Gantz JA, Fugate JA, Muskheli V, Gough GM, Vogel KW, Astley CA, Hotchkiss CE, Baldessari A, Pabon L, Reinecke H, Gill EA, Nelson V, Kiem H-P, Laflamme MA, Murry CE. Human embryonic-stem-cell-derived cardiomyocytes regenerate non-human primate hearts. Nature. 2014;510:273-277.

9. Bellamy V, Vanneaux V, Bel A, Nemetalla H, Boitard SE, Farouz Y, Joanne P, Perier M-C, Robidel E, Mandet C, Hagège A, Bruneval P, Larghero J, Agbulut O, Menasché P. Long-term functional benefits of human embryonic stem cell-derived cardiac progenitors embedded into a fibrin scaffold. J Heart Lung Transplant Off Publ Int Soc Heart Transplant. 2014; pii: S10532498(14)01432-6. doi: 10.1016/j.healun.2014.10.008.

10. Agbulut O, Menot M-L, Li Z, Marotte F, Paulin D, Hagège AA, Chomienne C, Samuel J-L, Menasché P. Temporal patterns of bone marrow cell differentiation following transplantation in doxorubicin-induced cardiomyopathy. Cardiovasc Res. 2003;58:451-459.

11. Pouly J, Hagège AA, Vilquin J-T, Bissery A, Rouche A, Bruneval P, Duboc D, Desnos M, Fiszman M, Fromes Y, Menasché P. Does the functional efficacy of skeletal myoblast transplantation extend to nonischemic cardiomyopathy? Circulation. 2004;110:1626-1631.

12. Hamdi H, Boitard S, Planat-Benard V, Pouly J, Neamatalla H, Joanne P, Perier M-C, Bellamy V, Casteilla L, Li Z, Hagège A, Mericskay M, Menasché P, Agbulut O. Efficacy of Epicardiallydelivered Adipose Stroma Cell Sheets in Dilated Cardiomyopathy. Cardiovasc Res. 2013; 99:6407. 
13. Gerbin KA, Murry CE. The winding road to regenerating the human heart. Cardiovasc Pathol Off J Soc Cardiovasc Pathol. 2015;24:133-140.

14. Lian X, Zhang J, Azarin SM, Zhu K, Hazeltine LB, Bao X, Hsiao C, Kamp TJ, Palecek SP. Directed cardiomyocyte differentiation from human pluripotent stem cells by modulating Wnt/ $\beta$ catenin signaling under fully defined conditions. Nat Protoc. 2013;8:162-175.

15. Hamdi H, Furuta A, Bellamy V, Bel A, Puymirat E, Peyrard S, Agbulut O, Menasché P. Cell delivery: intramyocardial injections or epicardial deposition? A head-to-head comparison. Ann Thorac Surg. 2009;87:1196-1203.

16. Hamdi H, Planat-Benard V, Bel A, Puymirat E, Geha R, Pidial L, Nematalla H, Bellamy V, Bouaziz P, Peyrard S, Casteilla L, Bruneval P, Hagège AA, Agbulut O, Menasché P. Epicardial adipose stem cell sheets results in greater post-infarction survival than intramyocardial injections. Cardiovasc Res. 2011;91:483-491.

17. Engler AJ, Sen S, Sweeney HL, Discher DE. Matrix elasticity directs stem cell lineage specification. Cell. 2006;126:677-689.

18. Jacot JG, McCulloch AD, Omens JH. Substrate stiffness affects the functional maturation of neonatal rat ventricular myocytes. Biophys J. 2008;95:3479-3487.

19. Kassiri Z, Khokha R. Myocardial extra-cellular matrix and its regulation by metalloproteinases and their inhibitors. Thromb Haemost. 2005;93:212-219.

20. Pelouch V, Dixon IM, Golfman L, Beamish RE, Dhalla NS. Role of extracellular matrix proteins in heart function. Mol Cell Biochem. 1993;129:101-120.

21. Sell SA, McClure MJ, Garg K, Wolfe PS, Bowlin GL. Electrospinning of collagen/biopolymers for regenerative medicine and cardiovascular tissue engineering. Adv Drug Deliv Rev. 2009;61:1007-1019.

22. Travis J. Sill, Horst A. von Recum, "Electrospinning: Applications in drug delivery and tissue engineering", Biomaterials 29 (2008) 1989-2006.

23. Mukherjee, S., Venugopal, J. R., Ravichandran, R., Ramalingam, M., Raghunath, M. and Ramakrishna, S. (2013) Nanofiber Technology for Controlling Stem Cell Functions and Tissue Engineering, in Micro and Nanotechnologies in Engineering Stem Cells and Tissues (eds M. Ramalingam, E. Jabbari, S. Ramakrishna and A. Khademhosseini), John Wiley \& Sons, Inc., Hoboken, New Jersey. doi: 10.1002/9781118574775.ch2.

24. Zi Yin, Xiao Chen, Hai-Xin Song, Jia-Jie Hu, Qiao-Mei Tang, Ting Zhu, Wei-Liang Shen, Jia-Lin Chen, Huanhuan Liu, Boon Chin Heng, Hong-Wei Ouyang, "Electrospun scaffolds for multiple tissues regeneration in vivo through topography dependent induction of lineage specific differentiation", Biomaterials 44 (2015) 173-185.

25. Kitsara M, Joanne P, Boitard SE, Ben Dhiab I, Poinard B, Menasché P, Gagnieu C, Forest P, Agbulut $\mathrm{O}$, Chen Y. Fabrication of cardiac patch by using electrospun collagen fibers. Microelectron Eng. 2015;144:46-50.

26. Dong B, Arnoult O, Smith ME, Wnek GE. Electrospinning of Collagen Nanofiber Scaffolds from Benign Solvents. Macromol Rapid Commun. 2009;30:539-542.

27. Jiang Q, Reddy N, Zhang S, Roscioli N, Yang Y. Water-stable electrospun collagen fibers from a non-toxic solvent and crosslinking system. J Biomed Mater Res A. 2013;101:1237-1247. 
28. Pernot M, Couade M, Mateo P, Crozatier B, Fischmeister R, Tanter M. Real-time assessment of myocardial contractility using shear wave imaging. J Am Coll Cardiol. 2011;58:65-72.

29. Couade M, Pernot M, Prada C, Messas E, Emmerich J, Bruneval P, Criton A, Fink M, Tanter M. Quantitative assessment of arterial wall biomechanical properties using shear wave imaging. Ultrasound Med Biol. 2010;36:1662-1676.

30. Burridge PW, Matsa E, Shukla P, Lin ZC, Churko JM, Ebert AD, Lan F, Diecke S, Huber B, Mordwinkin NM, Plews JR, Abilez OJ, Cui B, Gold JD, Wu JC. Chemically defined generation of human cardiomyocytes. Nat Methods. 2014;11:855-860.

31. Parlakian A, Charvet C, Escoubet B, Mericskay M, Molkentin JD, Gary-Bobo G, Windt LJ De, Ludosky M-A, Paulin D, Daegelen D, Tuil D, Li Z. Temporally controlled onset of dilated cardiomyopathy through disruption of the SRF gene in adult heart. Circulation. 2005;112:29302939.

32. Koren MJ, Devereux RB, Casale PN, Savage DD, Laragh JH. Relation of Left Ventricular Mass and Geometry to Morbidity and Mortality in Uncomplicated Essential Hypertension. Ann Intern Med. 1991;114:345-352.

33. Lund LH, Edwards LB, Kucheryavaya AY, Benden C, Christie JD, Dipchand AI, Dobbels F, Goldfarb SB, Levvey BJ, Meiser B, Yusen RD, Stehlik J, International Society of Heart and Lung Transplantation. The registry of the International Society for Heart and Lung Transplantation: thirty-first official adult heart transplant report--2014; focus theme: retransplantation. $J$ Heart Lung Transplant Off Publ Int Soc Heart Transplant. 2014;33:996-1008.

34. Garbern JC, Lee RT. Cardiac stem cell therapy and the promise of heart regeneration. Cell Stem Cell. 2013;12:689-698.

35. Kochupura PV, Azeloglu EU, Kelly DJ, Doronin SV, Badylak SF, Krukenkamp IB, Cohen IS, Gaudette GR. Tissue-engineered myocardial patch derived from extracellular matrix provides regional mechanical function. Circulation. 2005;112:I144-I149.

36. Zimmerman SD, Karlon WJ, Holmes JW, Omens JH, Covell JW. Structural and mechanical factors influencing infarct scar collagen organization. Am J Physiol Heart Circ Physiol. 2000;278:H194-H200.

37. Macchiarelli G, Ohtani O, Nottola SA, Stallone T, Camboni A, Prado IM, Motta PM. A microanatomical model of the distribution of myocardial endomysial collagen. Histol Histopathol. 2002;17:699-706.

38. Engler AJ, Carag-Krieger C, Johnson CP, Raab M, Tang H-Y, Speicher DW, Sanger JW, Sanger JM, Discher DE. Embryonic cardiomyocytes beat best on a matrix with heart-like elasticity: scarlike rigidity inhibits beating. J Cell Sci. 2008;121:3794-3802.

39. Berry MF, Engler AJ, Woo YJ, Pirolli TJ, Bish LT, Jayasankar V, Morine KJ, Gardner TJ, Discher DE, Sweeney HL. Mesenchymal stem cell injection after myocardial infarction improves myocardial compliance. Am J Physiol Heart Circ Physiol. 2006;290:H2196-H2203.

40. Chaturvedi RR, Herron T, Simmons R, Shore D, Kumar P, Sethia B, Chua F, Vassiliadis E, Kentish JC. Passive stiffness of myocardium from congenital heart disease and implications for diastole. Circulation. 2010;121:979-988.

41. Rossini A, Frati C, Lagrasta C, Graiani G, Scopece A, Cavalli S, Musso E, Baccarin M, Di Segni M, Fagnoni F, Germani A, Quaini E, Mayr M, Xu Q, Barbuti A, DiFrancesco D, Pompilio G, 
Quaini F, Gaetano C, Capogrossi MC. Human cardiac and bone marrow stromal cells exhibit distinctive properties related to their origin. Cardiovasc Res. 2011;89:650-660.

42. Oskouei BN, Lamirault G, Joseph C, Treuer AV, Landa S, Silva J Da, Hatzistergos K, Dauer M, Balkan W, McNiece I, Hare JM. Increased potency of cardiac stem cells compared with bone marrow mesenchymal stem cells in cardiac repair. Stem Cells Transl Med. 2012;1:116-124.

43. Li T-S, Cheng K, Malliaras K, Smith RR, Zhang Y, Sun B, Matsushita N, Blusztajn A, Terrovitis J, Kusuoka H, Marbán L, Marbán E. Direct comparison of different stem cell types and subpopulations reveals superior paracrine potency and myocardial repair efficacy with cardiosphere-derived cells. J Am Coll Cardiol. 2012;59:942-953.

44. Zheng S-X, Weng Y-L, Zhou C-Q, Wen Z-Z, Huang H, Wu W, Wang J-F, Wang T. Comparison of cardiac stem cells and mesenchymal stem cells transplantation on the cardiac electrophysiology in rats with myocardial infarction. Stem Cell Rev. 2013;9:339-349.

45. Citro L, Naidu S, Hassan F, Kuppusamy ML, Kuppusamy P, Angelos MG, Khan M. Comparison of human induced pluripotent stem-cell derived cardiomyocytes with human mesenchymal stem cells following acute myocardial infarction. PLoS ONE. 2014;9:e116281.

46. Fernandes S, Naumova AV, Zhu WZ, Laflamme MA, Gold J, Murry CE. Human embryonic stem cell-derived cardiomyocytes engraft but do not alter cardiac remodeling after chronic infarction in rats. J Mol Cell Cardiol. 2010;49:941-949.

47. Tian L, Hires SA, Mao T, Huber D, Chiappe ME, Chalasani SH, Petreanu L, Akerboom J, McKinney SA, Schreiter ER, Bargmann CI, Jayaraman V, Svoboda K, Looger LL. Imaging neural activity in worms, flies and mice with improved GCaMP calcium indicators. Nat Methods. 2009;6:875-881.

48. Higuchi T, Miyagawa S, Pearson JT, Fukushima S, Saito A, Tsuchimochi H, Sonobe T, Fujii Y, Yagi N, Astolfo A, Shirai M, Sawa Y. Functional and Electrical Integration of Induced Pluripotent Stem Cell-Derived Cardiomyocytes in a Myocardial Infarction Rat Heart. Cell Transplant. 2015; PMID:25606821.

49. Diguet N, Mallat Y, Ladouce R, Clodic G, Prola A, Tritsch E, Blanc J, Larcher J-C, Delcayre C, Samuel J-L, Friguet B, Bolbach G, Li Z, Mericskay M. Muscle creatine kinase deficiency triggers both actin depolymerization and desmin disorganization by advanced glycation end products in dilated cardiomyopathy. J Biol Chem. 2011;286:35007-35019.

50. Franco CA, Blanc J, Parlakian A, Blanco R, Aspalter IM, Kazakova N, Diguet N, Mylonas E, Gao-Li J, Vaahtokari A, Penard-Lacronique V, Fruttiger M, Rosewell I, Mericskay M, Gerhardt $\mathrm{H}, \mathrm{Li}$ Z. SRF selectively controls tip cell invasive behavior in angiogenesis. Dev Camb Engl. 2013;140:2321-2333.

51. Twardowski T, Fertala A, Orgel JPRO, San Antonio JD. Type I collagen and collagen mimetics as angiogenesis promoting superpolymers. Curr Pharm Des. 2007;13:3608-3621.

52. Krishnamurthy P, Peterson JT, Subramanian V, Singh M, Singh K. Inhibition of matrix metalloproteinases improves left ventricular function in mice lacking osteopontin after myocardial infarction. Mol Cell Biochem. 2009;322:53-62.

53. Al-Daccak R, Charron D. Allogenic benefit in stem cell therapy: cardiac repair and regeneration. Tissue Antigens. 2015;86:155-162. 
54. Ye J, Gaur M, Zhang Y, Sievers RE, Woods BJ, Aurigui J, Bernstein HS, Yeghiazarians Y. Treatment with hESC-Derived Myocardial Precursors Improves Cardiac Function after a Myocardial Infarction. PLoS ONE. 2015;10:e0131123.

55. Kolossov E, Bostani T, Roell W, Breitbach M, Pillekamp F, Nygren JM, Sasse P, Rubenchik O, Fries JWU, Wenzel D, Geisen C, Xia Y, Lu Z, Duan Y, Kettenhofen R, Jovinge S, Bloch W, Bohlen H, Welz A, Hescheler J, Jacobsen SE, Fleischmann BK. Engraftment of engineered ES cell-derived cardiomyocytes but not BM cells restores contractile function to the infarcted myocardium. J Exp Med. 2006;203:2315-2327. 


\section{Figure legends}

Figure 1. Electrospun collagen scaffold structure and stiffness. (A-B) Scanning electron microscopy images of 5\% (A) or 10\% (B) CA-cross-linked collagen scaffold baked at $150^{\circ} \mathrm{C}$ for 150 minutes. (C) Stiffness (Young's Modulus) of the different collagen scaffolds evaluated by Shear Wave Elastography. CA, citric acid. Scale bar: $1 \mu \mathrm{m}(\mathrm{A}-\mathrm{B}) .{ }^{*} p$-value $<0.01$.

Figure 2. Biocompatibility of collagen scaffolds: in vivo (A-D) and in vitro (E-F) assessments. (AD) $5 \%$ and $10 \% \mathrm{CA}$ collagen scaffolds were epicardially delivered on the surface of the heart of healthy C57BL6 mice $(n=24)$. After 7 days, the hearts were explanted and analyzed. (A-B) Representative images of hematoxylin-eosin staining of a heart section seven days after implantation. (C) Post-implantation porosity of scaffolds as a marker for their resistance and degradability. (D) Capillary infiltration in scaffold assessed by CD31 and caveolin- $1 \alpha$ immunolabelings. (E-F) In vitro biocompatibility was tested with neonatal rat cardiomyocytes. (E) Immunostaining against $\alpha$-actinin (green) and Nkx2.5 (red); nuclei appear blue due to Hoescht 33342 staining. (F) Number of cardiomyocytes on the scaffolds, expressed as a percentage of total cells, after 3 days of culture and immunolabeling against $\alpha$-actinin, CA, citric acid. Scale bar: $100 \mu \mathrm{m}(\mathrm{A}, \mathrm{B}, \mathrm{D}, \mathrm{F}) .{ }^{*} p$-value $<0.05$, $* * p$-value $<0.01$.

Figure 3. Lack of adverse functional effects of acellular collagen scaffolds. Assessment, at 14 days after implantation in a non-ischemic dilated $\alpha$ MHC-MerCreMer:Sf/Sf mice, of left ventricular ejection fraction (A), left ventricular end-systolic volume (B), left ventricular end-diastolic volume (C) and gene expression of $\beta-\mathrm{MHC}(\mathrm{D})$, Anf (E) and Bnp (F).

Figure 4. Improvement of cardiac function in a non-ischemic dilated $\alpha \mathrm{MHC}$-MerCreMer:Sf/Sf mouse model following epicardial implantation of the cellularized collagen scaffold. $10 \% \mathrm{CA}$ collagen scaffold was seeded with cardiomyocytes derived from human induced pluripotent stem cell (hiPS-CM) and cultured for 3 days. (A) Schematic representation of the cardiac specification protocol used to obtain cardiomyocytes from hiPS cells. (B) Flow cytometry showing that after 15 days of cardiac differentiation, more than $70 \%$ of hiPS cell-derived cells are positive for cardiac troponin $\mathrm{T}$ (cTnT). (C) Immunolabeling against $\alpha$-actinin of hiPS-CM seeded onto a $10 \%$ CA collagen scaffold for 3 days. Note the bona fide structure of the cardiomyocytes on the scaffold. (D-G) Cellularized scaffolds (10\% CA+hiPS-CM) were epicardially delivered in 8 immunosuppressed $\alpha \mathrm{MHC}$ MerCreMer:Sf/Sf mice. Six cell-free 10\% CA collagen scaffold-implanted mice were used as controls. Fourteen days after implantation, left ventricular end-systolic volume (D), left ventricular end-diastolic volume (E) and ejection fraction $(\mathrm{F})$ were evaluated. Note the significant improvement of heart function in mice receiving the cellularized collagen scaffolds. (G) Relative expression, normalized to sham, of mRNA by real-time PCR for some stress-induced genes. $\beta$-MHC, beta-myosin heavy chain; ACTC1, cardiac $\alpha$ actin; cTnT, cardiac troponin T; CA, citric acid; hiPS-CM, cardiomyocyte-derived from human induced pluripotent stem cells. Scale bar: $30 \mu \mathrm{m}(\mathrm{C}) .{ }^{*} p$-value $<0.05$, $* * * p$-value $<0.001$.

Figure 5. Capillary density (A, B and D) and serum response factor expression $(C)$ in treated mice. (A-B, D) Capillary infiltration, as assessed by CD31 immunolabeling in $10 \%$ CA (A) and $10 \%$ CA+hiPS-CM-treated animals (B). (C) Relative quantification of mRNA level by real-time PCR of the SRF gene. Scale bars: $250 \mu \mathrm{m}(\mathrm{A}-\mathrm{B}), 80 \mu \mathrm{m}$ (D). ${ }^{*} p$-value $<0.05,{ }^{* *} p$-value $<0.01$.

Figure 6. Effects of scaffold cellularization on its relationship with the underlying myocardium. Hematoxylin-eosin (A, C) and Sirius red (B, D) staining of 10\% CA (A-B) and 10\% CA+hiPS-CM (C-D) collagen scaffolds after 14 days of implantation. *indicate interstitial infiltration of cells. (E) Quantification of the area of positive staining for Sirius red relative to the total area of the left ventricular section. (F) Relative quantification of mRNA levels by real-time PCR for some genes 
involved in remodeling of the extracellular matrix. Timp1, tissue inhibitor of metalloproteinase 1; Thy1, thymus cell antigen-1; Col, Collagen. Scale bar: $400 \mu \mathrm{m}$ (A-D). 

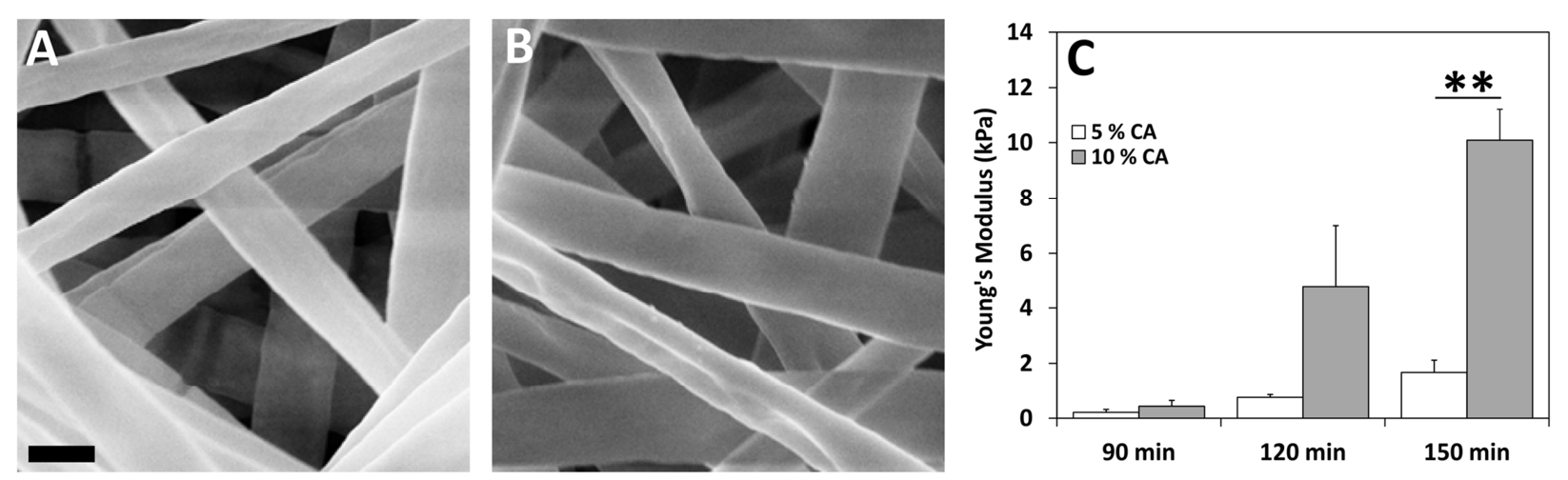

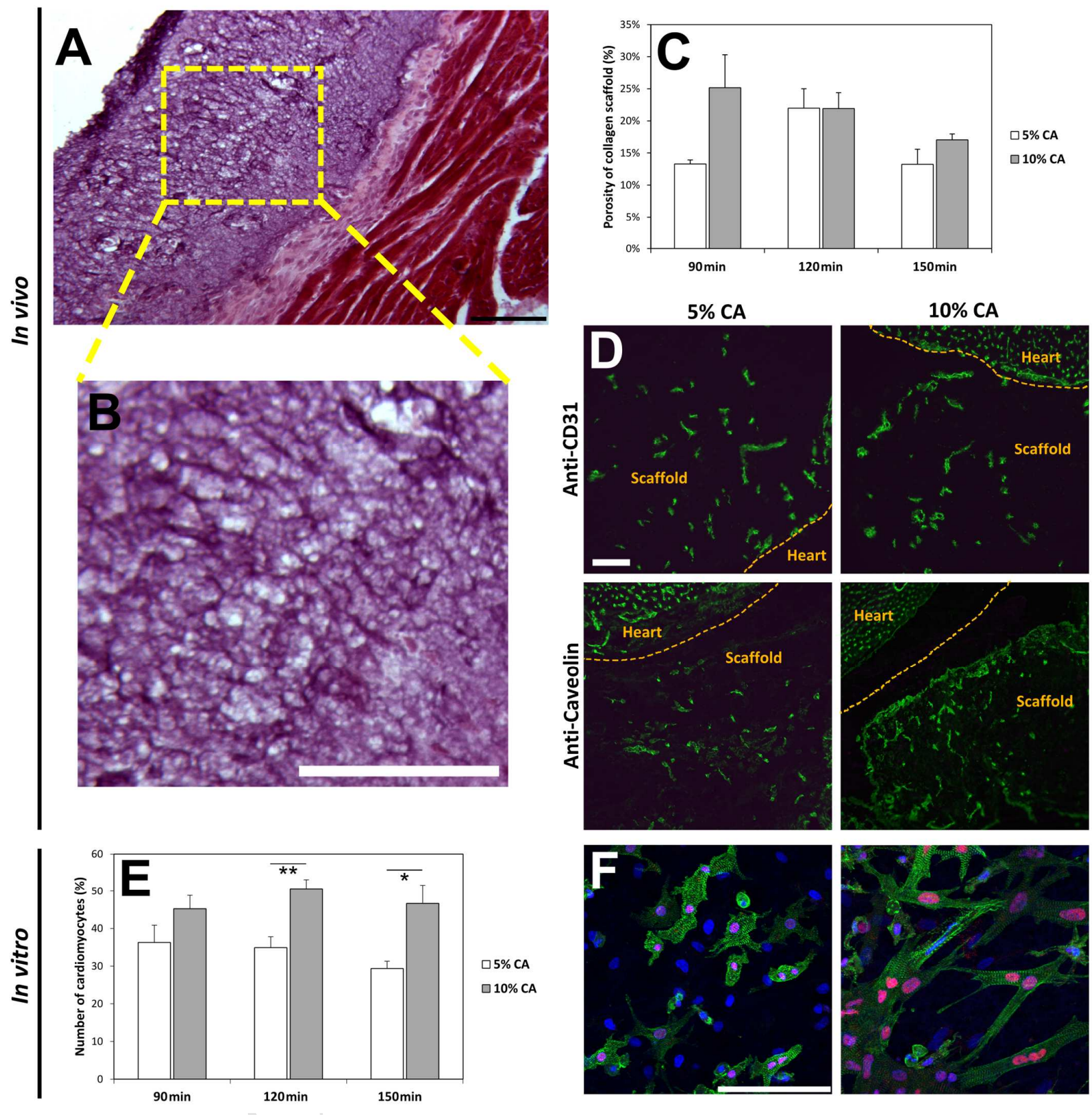

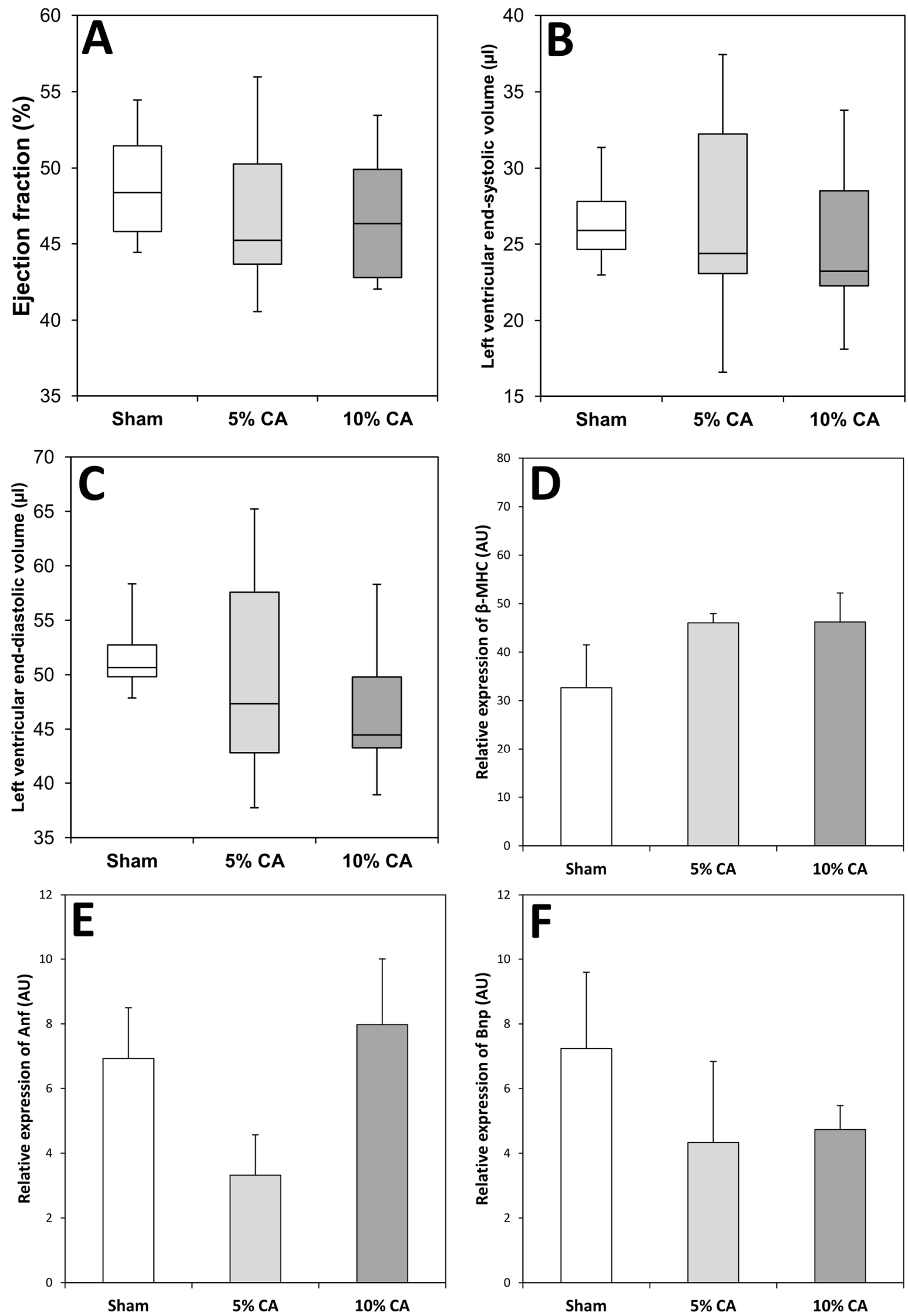

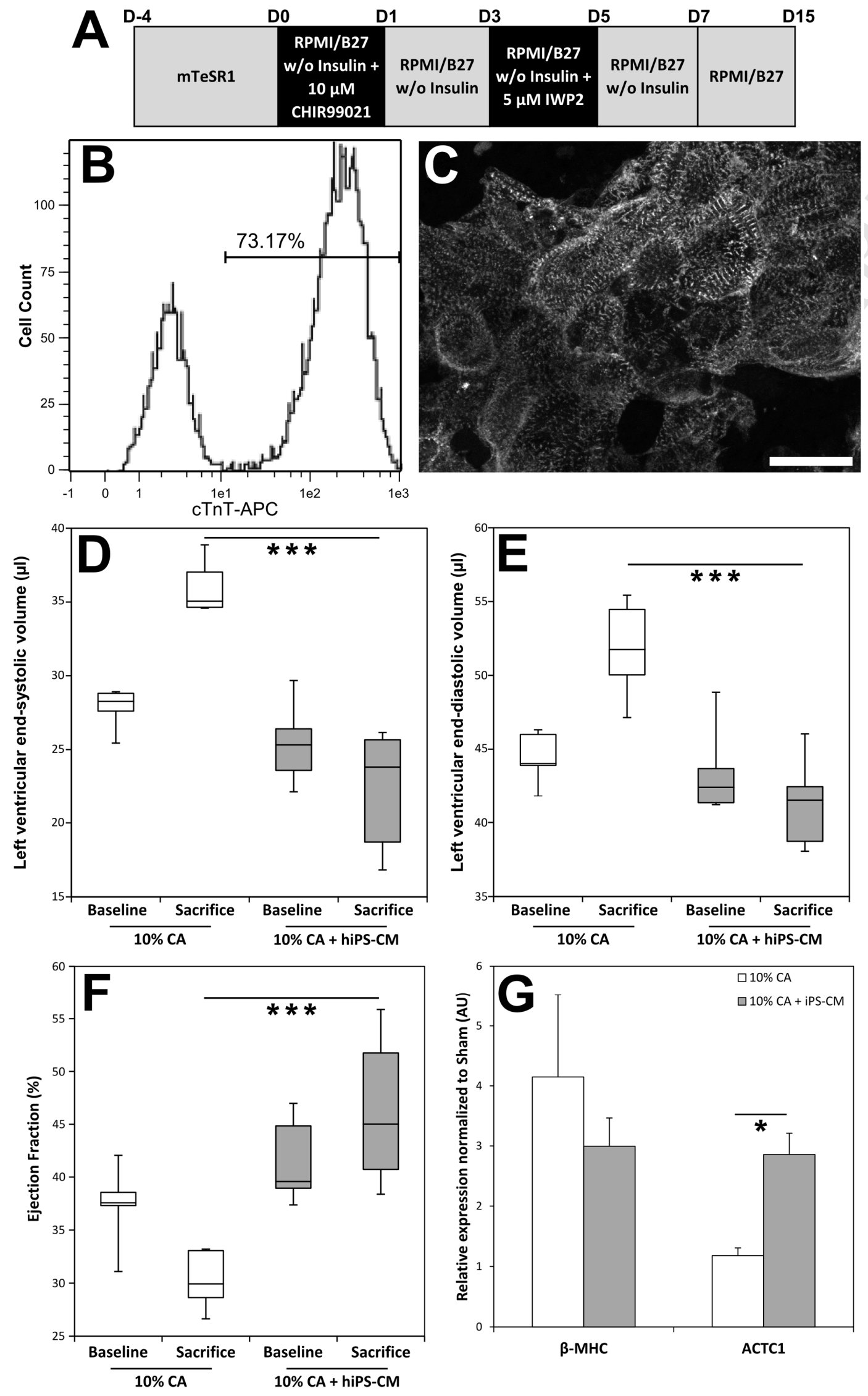

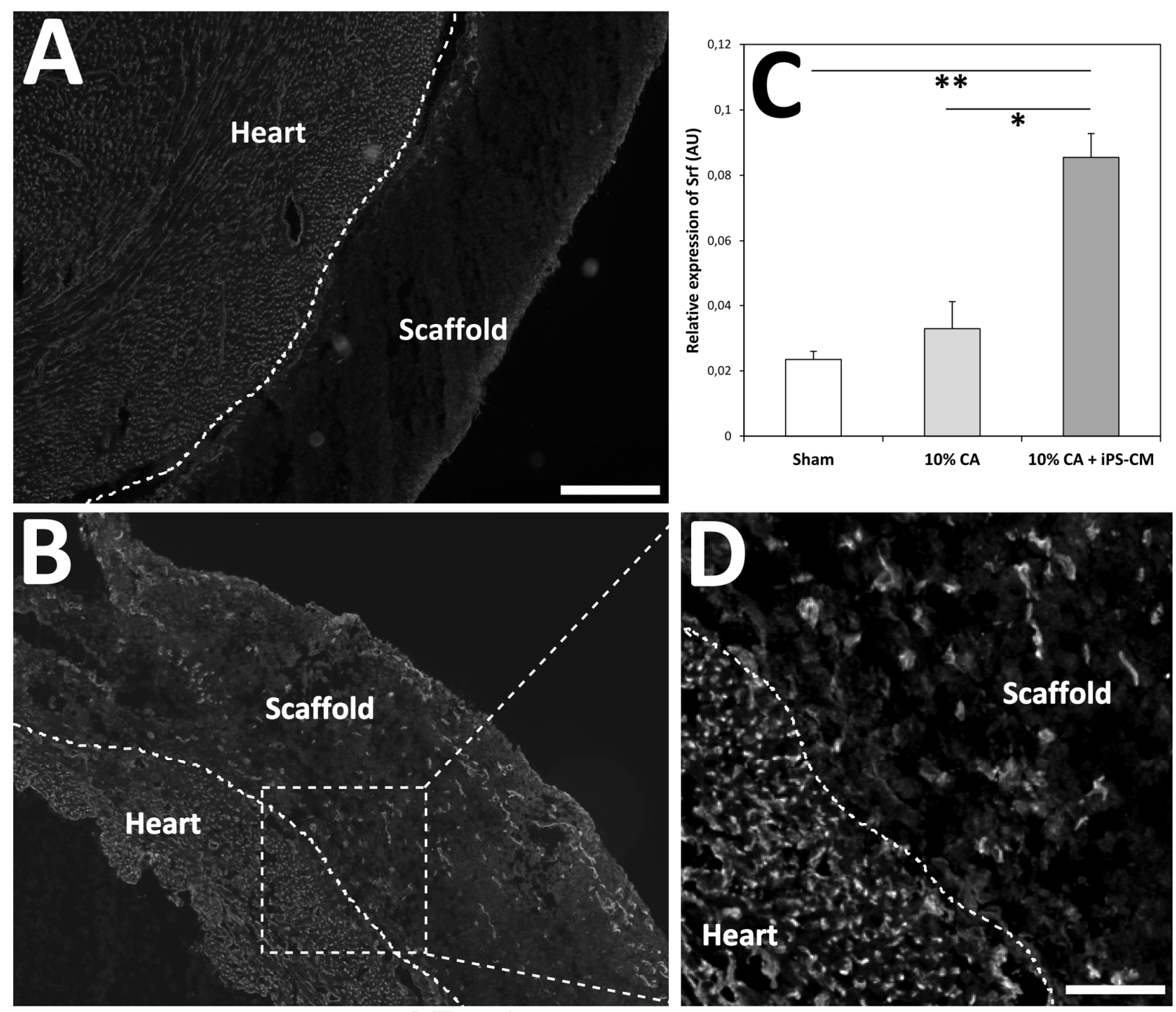
$10 \% \mathrm{CA}$

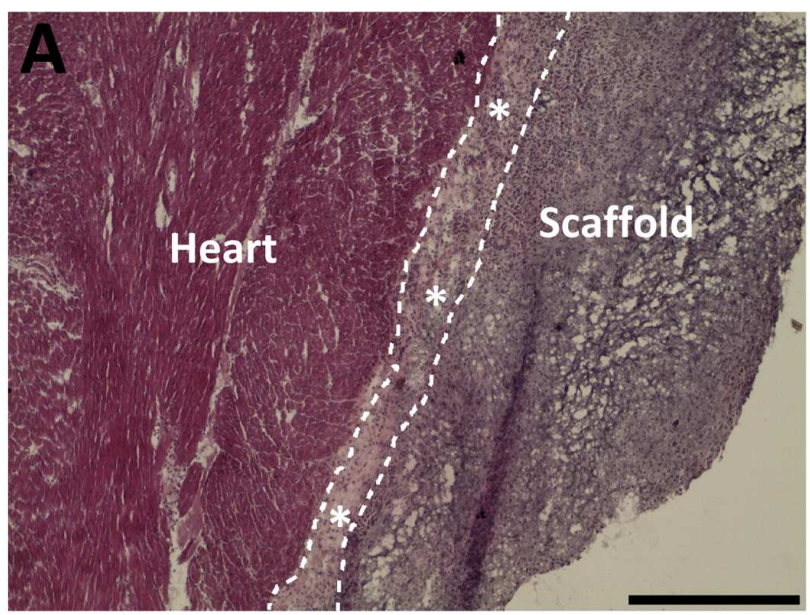

B
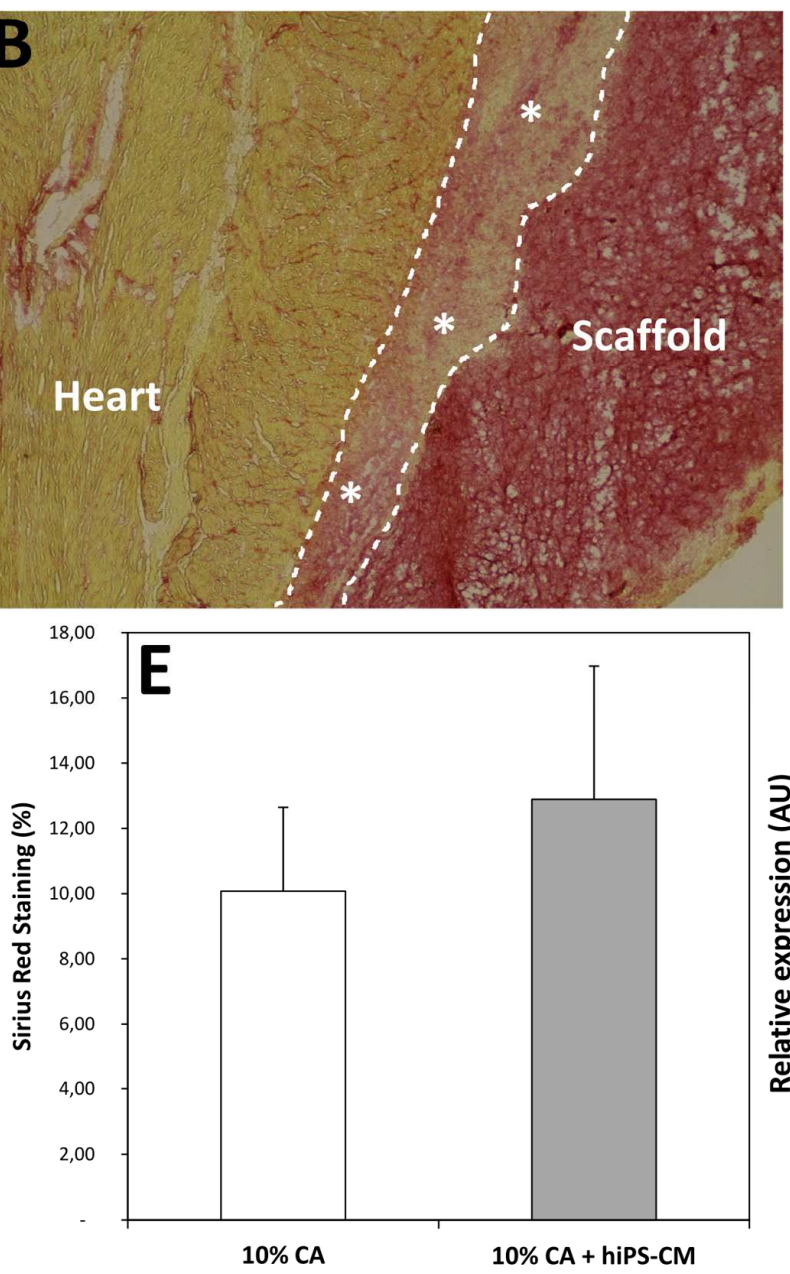

$10 \%$ CA + hiPS-CM
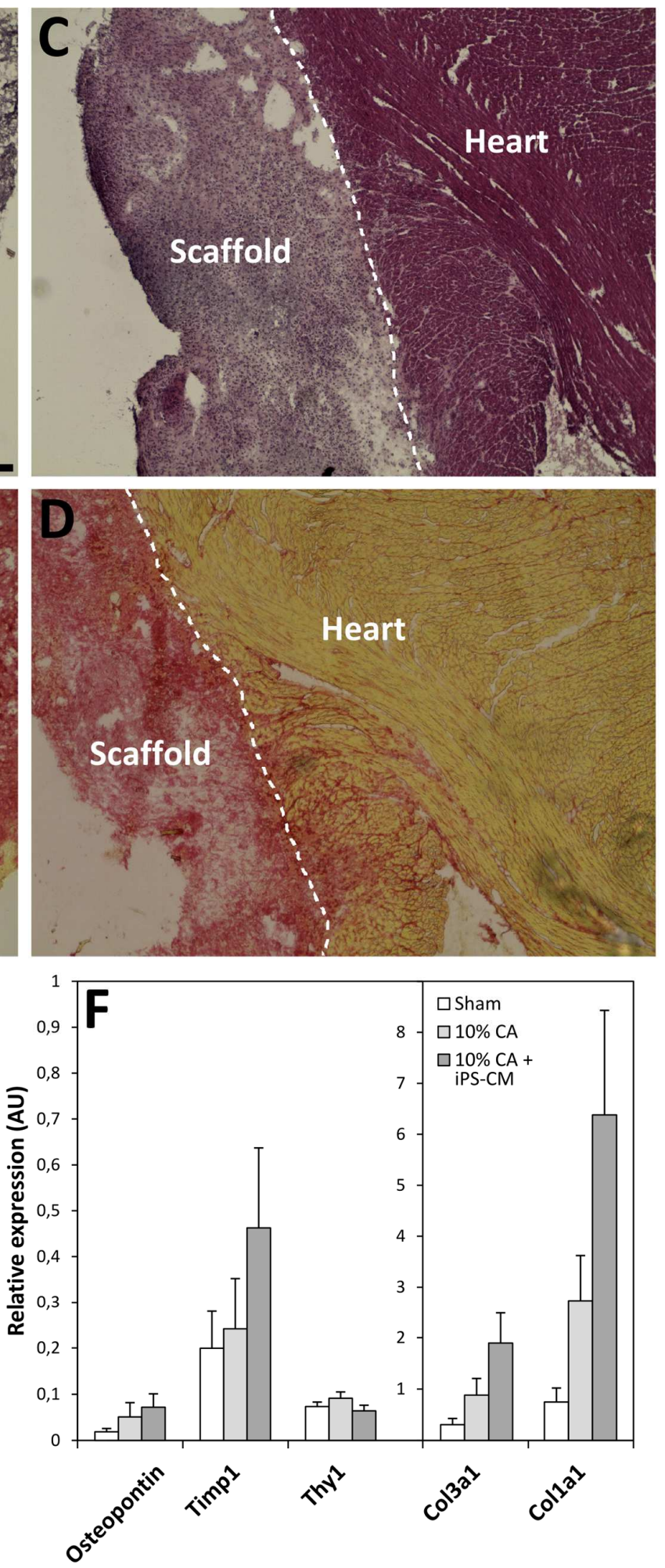